\title{
Photosynthetic Pigments Content of Trapa Natans Specie in Skadar Lake
}

\author{
Albana Temali ${ }^{1}$, Arjana Ylli (Kraja) ${ }^{2}$ \\ ${ }^{1}$ Department of Biology-Chemistry Faculty of Natural Science, University Luigj Gurakuqi, Shkoder, Albania \\ ${ }^{2}$ Department of Biotechnology Faculty of Natural Sciences University of Tirana, Albania
}

\begin{abstract}
Skadar lake is the largest lake in th Balkan Peninsula. The total area is $5500 \mathrm{~m}^{2}$. Terretorialy the lake belong to Montenegro and to Albania. Both the sides of lake is a big development of acquatic vegetation, including a large variety of habitats and biological communities. The most important associations are Potameto-Najadetum, Trapetum natantis, Myriophyllo-Nupharetum, Nymphoideum peltata. These associations include lake shore macrophytes Najas, Vallisneria, Potamogeton, floating macrophytes Nuphar luteum, Trapa natans, Numphaea alba. Emersed water macrophytes are developed on both sides of lake predominantly in the eastern part of lake (Kamice Shegan) which go as far as 3 meter deep such Ceratophyllum, Najas marina, Najas minor, Vallisneria.Trapeum natantisi is largely widespread community in the Skadar lake. Waternuts develops wide population and communities in the inner and deeper part of the floating macrophyta zones. Plant samples were collected on the both sides of the lake. For Trapa natans specie is determined the content of photosynthetic pigments, chlorophyll $a$, chlorophyll $b$ and carotenoids. Photosynthetic pigments were extracted with $80 \%$ acetone and their concentrations are expressed in $\mathrm{mg} / \mathrm{g}$ dry absolutely leaf. Their measurement is made in the bands $f$ 663, 645.470, of spectriphotometer. Trapa natans was found in the eastern shore and in western shore of Skadar lake. The highest values of chlorophyll $a$ an $b$ in the species Trapa natans was found in September 2014.
\end{abstract}

Keywords - acquatic vegetation, habitats macrophytes, photosynthetic pigments, Skadar lake.

\section{INTRODUCTION}

Skadar lake is the largest lake on Balkan Peninsula. The drainage area of the lake is about $5500 \mathrm{~km}^{2}, 4.470 \mathrm{~km}^{2}$ in Montenegro and $1030 \mathrm{~km}^{2}$ in Albania. The lake area is 368 $\mathrm{km}^{2}$. The lake volume varies between $1.8 \mathrm{~km}^{2}$ in dry perods to $4.1 \mathrm{~km}^{3}$ during wet periods. The lake depth is about 7-10 $\mathrm{m}$ and the maximum lake depth reaches $44 \mathrm{~m}$.[1]
Skadar lake is known as a hight biodiversity ecosystem. The variety of the species per $100 \mathrm{~m}^{2}$ is $\mathrm{S} / \mathrm{A}=0.8752$. We can mention important habitats like: the Eye of Shegan, the Eye of Viri, the underwater meadows in Shegan, the reedsxunkth in Shkoder, Vrake and Buze Uje, the forests of the shores in the areas of Shegan - Kamice, Shkoder-Vrake, Zogaj-Shiroke.[5]

Aquatic and wetland flora is very rich. About 242 species of macrophytes are known from which 10 are algae(Characeae), 1 musk, 1 fir. 7 Species are members of Equisetaceae family, 115 are Monocotyledons and 107 Dicoyiledons. [2]

The most important associations of the vegetations types according to Pulevic et al(2001) are : Najadetum marinae ,Potameo-Najadetum, Potameo- Vallisnerietum, Potameonatantis, Trapeum-natantis. Myriophyllo-Nupharetum lutei, Nymphoidetum peltata, Phragmitetum australis, Tyhpaetum latifolia, Ludwigetum palustris, Leucojo-Fraxinetum angustifolia.[5]

Summary of the most important asociations of the vegetation types

Najadetum marinae (Fukarek 1961) assemblage overgrow the Lake bottom in depths zones more than $3 \mathrm{~m}$. This community is the most resistant on light deficiency. Dominant species is Najas marina but there are also species like Potamogeton perfoliatus, Myriophyllum spicatum, and Vallisneria spiralis. The mentioned species are typical hydrophyte.[3]

Potametum perfoliati association is common in the depth zones between 1 and 3 meters and is characterized by higher species diversity then others associations in the Lake. This association inhabits areas with colder water. Dominant species is Potamogeton perfoliatus and all other constituents are in hydrophyte type of plants. Constituents include: Myriophyllum spicatum, Myriophyllum verticillatum, Potamogeton crispus, Potamogeton pectinatus, Ceratophyllum demersum.[3] 
Potametum lucentis is a community that develops in inshore part of the lake .Dominant species of this community are Potamogeton lucens and Ceratophyllum demersum while others are far less abundant.[3]

Myriophyllo -Nupharetum lutei include species from Potamion association: Najas marina, Najas minor, Potamogeton perfoliatus, Potamogeton. crispus. It is characterized by presence of species Nuphar luteum,. This association inhabits colder water masses in littoral and are in contrast to association Nymphoidetum peltatae that inhabits wormer water masses of littoral

Floating vegetation is also represented by the communities Nymphaeto-Nupharetum lutei Lakušić 1965 and Trapetum natantis T h. Mull. Et Gors. 60.

Trapetum natantisi is largely widespread community in the /Skadar Lake. Water-nut develops wide population and communities in the inner and deeper part of the floating macrophyta zones as a continuous belt connecting this zone with that of the submerged vegetation .[3]

Between a large number of plant species it is necessary to make a selection of species that are considered «target species». Target species are defined the species which meet the one of the criteria of the Berne Convention. In the area of Skadar lake are 3 globally threatened species Trapa natans, Marsilea quadrifolia dhe Caldensia parnassifolia [2]

Trapa natans is an herbaceous, floating-leaf aquatic species that often grows in water around $60 \mathrm{~cm}$ deep. The floating leaves are arranged an a rosette,with leathery upper leaves up to $5 \mathrm{~cm}$ wide and broadly rhomboid,triangular. The species also produces submersed leaves that are morphologically different. The fruit is a horned nut- like structure that develops underwater and is approximately $3 \mathrm{~cm}$ wide. The stems of plants is flexible and from 1 to $5 \mathrm{~m}$ long,nodes of the stem have slender linear roots, while. The plant is anchored in the sediment by the lower roots that emerged from the propagating seed hull. Trapa natans is found world-wide in full sun and lowe energy, nutrient-rich fresh waters. The species is disturbance tolerant:it has been shown that sewage inputs create favorable conditions of increased alkalinity for the plant and that increased nitrogen is correlated with increased petiole and fruit biomass.[4]

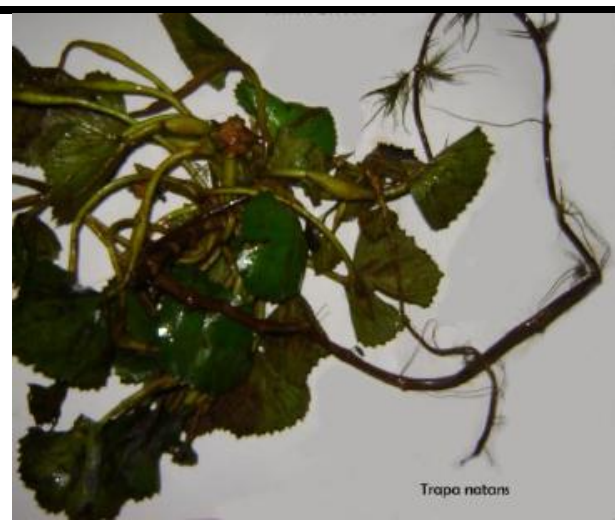

Fig.1: Trapa natans found in Skadar lake

\section{MATERIAL AND METHODS}

It was collected plant samples in 6 stations from October 2013 to October 2014. In the laboratory it was made made the identification of collected samples using floras and keys of vascular plants. The samples collected are submited to the treatement for the determination of photosynthetic pigments.

For extraction we have taken the midsection of the leafs. Samples are placed in a PES filters to calculate the content of the pigments referred to the dry matter weight. As a solvent is used the acetone considered the most suitable for extraction in the case of tissue with high water content. Based on properties that have chlorophyll as volatile substances, all operations for the extractions are performed as soon as possible. During the work we have avoided the direct sun light. For each sample we determined the humidity to calculate the content of pigments referred in $\mathrm{mg} / \mathrm{ml}$ and in $\mathrm{mg} / \mathrm{g}$ dry matter. Determination of pigment is made on the basis of non-destructive spectrophotometric method. Absorption spectra of chlorophyll a, chlorophyll b and carotenoids allow to determine the content of the pigments in the extract without preliminary separation at $663,645.470$ wavelengths. To determine the content of pigments are used Rebelen equations.

\section{RESULTS AND DISCUSSION}

In the collected samples it was found; station Shkodra 1 Ceratophyllum demersum and Potamogeton perfoliatum, in Shiroke (Station 2) the specie Vallisneria spiralis. It was faund Najas marina species in western and eastern shore Zogaj(Station 3), Vrake, Koplik(Station 4). Trapa natans was found only in Shegan (Station 6) and Shiroke (Station 2). 


\begin{tabular}{||l||l|l||}
\hline Sampling points & Latitude & Longitude \\
\hline \hline S1 & $42^{\circ} 3^{\prime} 14^{\prime \prime} \mathrm{N}$ & $19^{\circ} 28^{\prime} 54^{\prime \prime} \mathrm{E}$ \\
\hline \hline S2 & $42^{\circ} 3^{\prime} 37^{\prime \prime} \mathrm{N}$ & $19 \circ 26^{\prime} 58^{\prime \prime} \mathrm{E}$ \\
\hline \hline S3 & $42^{\prime} 4^{\prime} 19^{\prime \prime} \mathrm{N}$ & $19^{\circ} 23^{\prime} 53^{\prime \prime} \mathrm{E}$ \\
\hline \hline S4 & $42^{\circ} 12^{\prime} 0.7^{\prime \prime} \mathrm{N}$ & $19^{\circ} 47^{\prime} 65^{\prime \prime} \mathrm{E}$ \\
\hline \hline S5 & $42^{\circ} 18^{\prime} 73^{\prime \prime} \mathrm{N}$ & $19 \circ 41^{\prime} 50^{\prime \prime} \mathrm{E}$ \\
\hline \hline S6 & $42 \circ 27^{\prime} 23^{\prime \prime} \mathrm{N}$ & $19 \circ 39^{\prime} 35^{\prime \prime} \mathrm{E}$ \\
& & \\
\hline
\end{tabular}

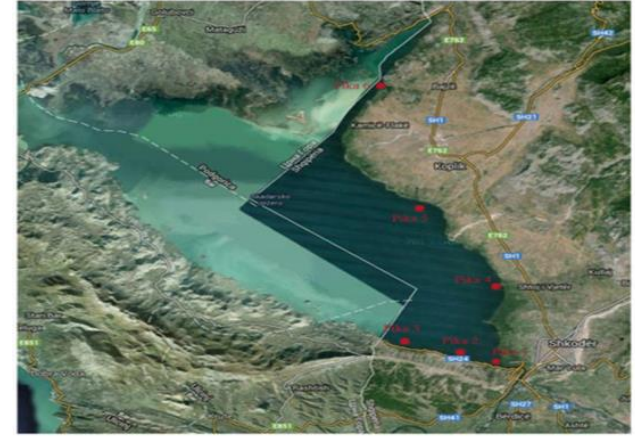

Fig.2: Coordinates of sampling points

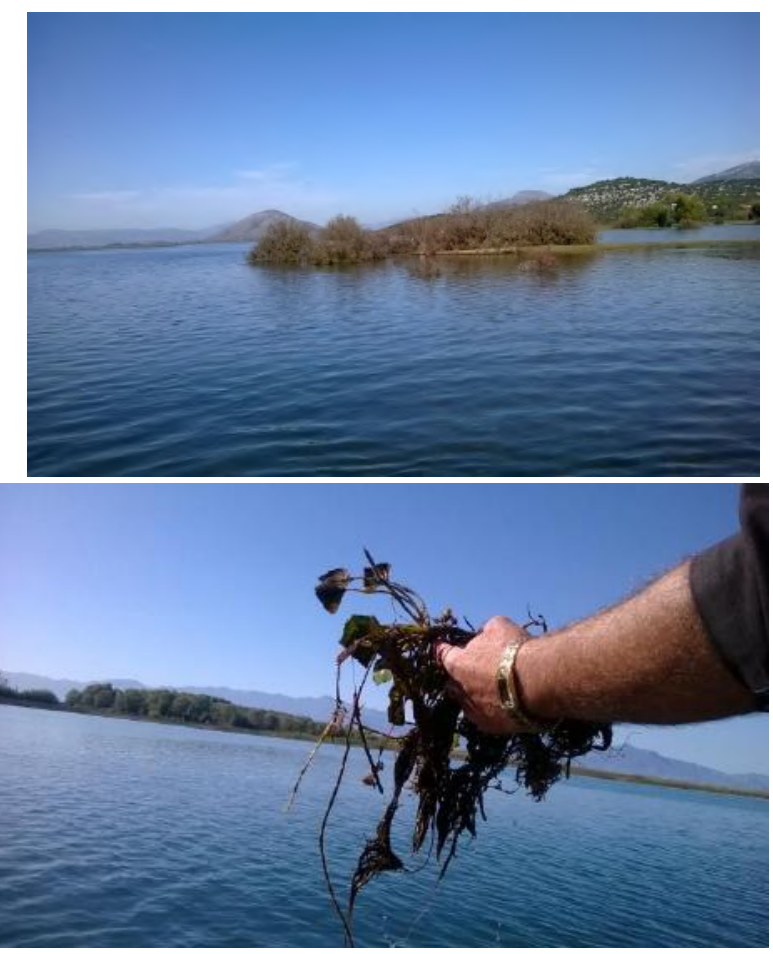

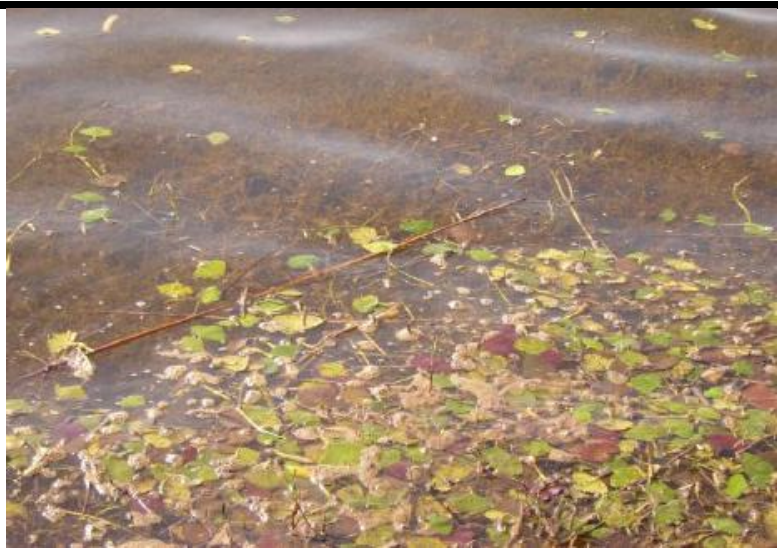

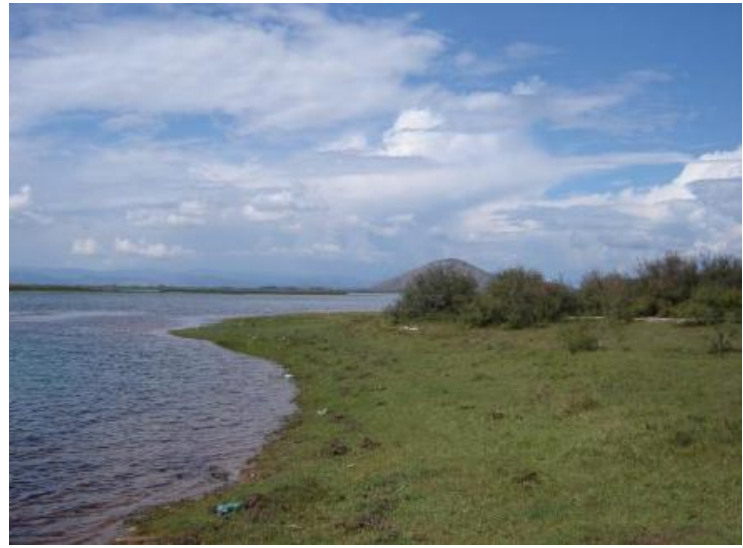

Fig.3: View of the station six Shegan situated in eastern shore line (Photo by A. Temali)

Table.2: Photosynthetic pigments content of Trapa natans specie during 2013-2014

Photosynthetic pigments content of Trapa natans specie during 2013-2014

\begin{tabular}{|c|c|c|c|c|c|c|c|}
\hline & $\begin{array}{l}\text { Teto } \\
\mathrm{r} \\
201 \\
3\end{array}$ & $\begin{array}{l}\text { Qersh } \\
\text { or } \\
2014\end{array}$ & $\begin{array}{l}\text { Korri } \\
\text { k } \\
2014\end{array}$ & $\begin{array}{l}\text { Shtato } \\
\text { r } 2014\end{array}$ & $\begin{array}{l}\text { Tetor } \\
2014\end{array}$ & Mes & $\begin{array}{l}\text { Dev } \\
\text {.s }\end{array}$ \\
\hline $\begin{array}{l}\text { Chla } \\
\text { (wet } \\
\text { weight } \\
\text { ) }\end{array}$ & 0.73 & 0.706 & $\begin{array}{l}0.28 \\
9\end{array}$ & 0.876 & 0.661 & 0.654 & 0.21 \\
\hline Chlb & 0.31 & 0.192 & $\begin{array}{l}0.14 \\
0\end{array}$ & 0.347 & 0.150 & 0.229 & 0.09 \\
\hline $\begin{array}{l}\text { Carote } \\
\text { noids }\end{array}$ & 0.31 & 0.237 & $\begin{array}{l}0.07 \\
1\end{array}$ & 0.276 & 0.191 & 0.218 & 0.09 \\
\hline $\begin{array}{l}\text { Chl(a+ } \\
\text { b) }\end{array}$ & 1.05 & 0.898 & 0.42 & 1.224 & 0.812 & 0.883 & 0.29 \\
\hline
\end{tabular}




\begin{tabular}{|c|c|c|c|c|c|c|c|}
\hline & & & 9 & & & & \\
\hline $\begin{array}{l}\text { Chla } \\
\text { (dry } \\
\text { weight } \\
\text { ) }\end{array}$ & 3.59 & 4.584 & $\begin{array}{l}1.19 \\
4\end{array}$ & 4.851 & 3.243 & 3.493 & 1.44 \\
\hline Chlb & 1.54 & 1.248 & $\begin{array}{l}0.58 \\
0\end{array}$ & 1.921 & 0.736 & 1.206 & 0.55 \\
\hline $\mathrm{x}+\mathrm{c}$ & 1.52 & 1.540 & $\begin{array}{l}0.29 \\
5\end{array}$ & 1.529 & 0.938 & 1.166 & 0.55 \\
\hline $\begin{array}{l}\mathrm{Chl}(\mathrm{a}+ \\
\text { b) }\end{array}$ & 5.13 & 5.832 & $\begin{array}{l}1.77 \\
4\end{array}$ & 6.772 & 3.979 & 4.698 & 2.29 \\
\hline $\begin{array}{l}\text { Chla/C } \\
\text { hlb }\end{array}$ & 2.36 & 3.818 & $\begin{array}{l}2.09 \\
2\end{array}$ & 2.598 & 4.502 & 3.074 & 1.03 \\
\hline $\begin{array}{l}(\mathrm{a}+\mathrm{b}) /( \\
\mathrm{xc})\end{array}$ & 3.35 & 3.791 & $\begin{array}{l}6.10 \\
3\end{array}$ & 4.420 & 4.254 & 4.385 & 1.04 \\
\hline
\end{tabular}

The maximum of chlorophyll $\mathrm{a}$ and $\mathrm{b}$ was observed in September 2014. The minimum of values of chlorophyll a and b was determined in july 2014 for wet and dry weight. Carotenoids have reached the maximum of values in October 2013 and the minimum values of carotenoids was obtained in july 2014 for wet dry. The carotenoids values for dry weight is higher in September 2014 while the lowest value for carotenoids(dry weight) is obtained in july 2014.

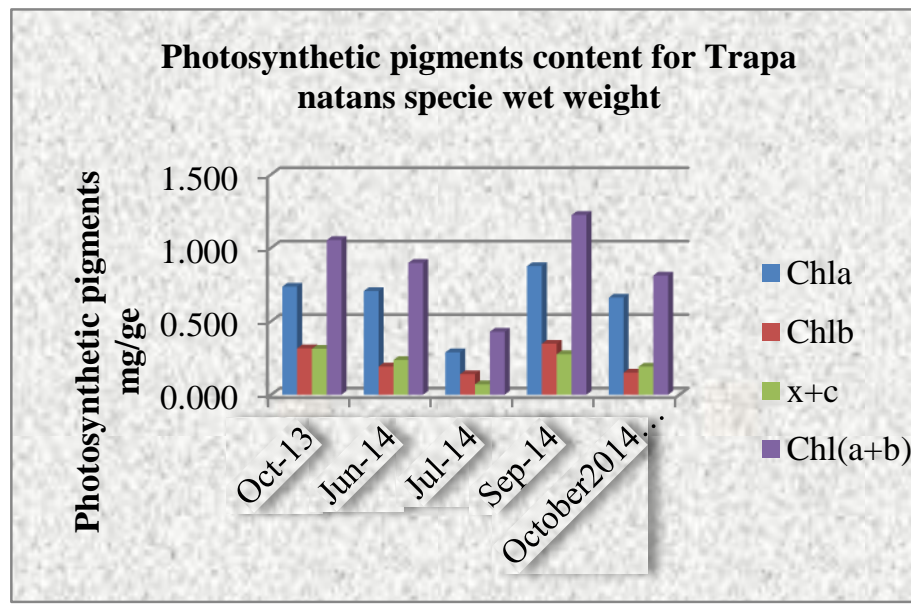

Fig.4: Photosynthetic pigment content in Trapa natans specie (wet weight)

\section{Photosynthetic pigments content in Trapa natans} specie dry-weight

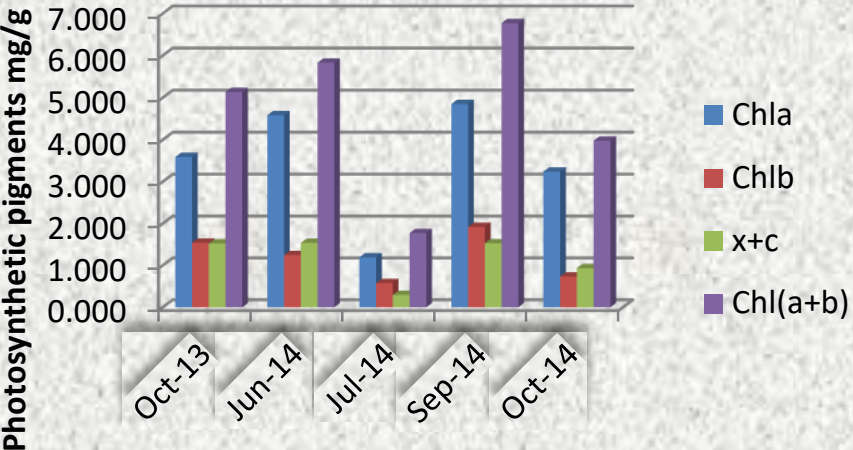

Fig.5: Photosynthetic pigment content in Trapa natans specie (dry weight)

\section{CONCLUSIONS}

The species found in western and eastern shore lines are part of the primary associations of Skadar lake.

Trapa natans as endangered specie was found in both sides of Skadar lake.

The hightest value of chlorophyll $\mathrm{a}$ and $\mathrm{b}$ present in Trapa natans specie was determined in September 2014. Carotenoids have the maximum of values in October 2013. The presence of considerable number of aquatic plants indicate that the quality of Skadar lake waters remains suitable to support the diversity of species.

\section{REFERENCES}

[1] Analysis. Albania \& Montenegro. World Bank (IBRD).( 2005): Final Report: Main Document. 9P6515: 23-24

[2] Anonymous. (2013): Habitats, Fora and Birds of Skadar lake, Tirana 2013): 75-78

[3] Anonymous.( 2013): Review, assess and classification of habitats status and accompanied species in the Transboundary Shkodra/Skadar Lake. Podgorica,: 8788

[4] Mikulyuk A., Nault.E .M 2009.Water chestnut (Trapa natans). A Technical Review of Distribution, Ecology, Impact and Management: 3-8 Rec ( 2009): Catalogue, Maj 2009 